\title{
Perilaku Antisosial Dalam Pandangan Islam
}

\author{
Haryani Putriani dan Ihsan Mz \\ Institut Agama islam negeri Palangkaraya
}

\begin{abstract}
This research was conducted to describe antisocial behavior in an Islamic perspective. Using qualitative methods in library research. Compile from various sources of relevant literature to find theories, propositions, principles, ideas, and opinions. Literary data is collected using the documentation method, so researchers get information not from several people as speakers, but from various written sources. This study reviews antisocial behavior from written documents in the form of published research and relevant books. While the study of Islamic view of this behavior is discussed through several propositions from the Koran and the Hadith. This research shows that antisocial behavior is not in line with the teachings of Islam because Islam through the Koran and Hadith asks each adherent to ta'aruf (know each other), interact with each other by promoting the ability of socialization, attitudes and good communication, while antisocial behavior is contrary to the principle.
\end{abstract}

Keywords: Alquran; Antisocial; Hadis; Islamic Perspective

\begin{abstract}
Abstrak
Penelitian ini dilakukan untuk mendeskripsikan perilaku antisosial dalam pandangan Islam. Menggunakan metode kualitatif dalam kajian pustaka (library research). Menghimpun dari berbagai sumber literatur yang relevan untuk menemukan teori, dalil, prinsip, ide, gagasan, dan pendapat. Data-data literatur ini dikumpulkan menggunakan metode dokumentasi, sehingga peneliti mendapatkan informasi bukan dari beberapa orang sebagai narasumber, melainkan dari beragam sumber tertulis. Penelitian ini mengulas mengenai perilaku antisosial dari dokumen tertulis berupa hasil riset yang telah terbit dan juga buku-buku yang relevan. Sementara kajian tentang pendangan Islam terhadap perilaku ini dikupas melalui beberapa dalil Alquran dan Hadis Nabi Saw. Penelitian ini menunjukkan bahwa perilaku antisosial tidak sejalan dengan ajaran Islam sebab Islam melalui Alquran dan Hadis menyuruh setiap pemeluknya untuk ta'aruf (saling kenal-mengenal), saling berinteraksi dengan mengedepankan kemampuan sosialisasi, sikap dan komunikasi yang baik, sementara perilaku antisosial bertolak belakang dengan prinsip tersebut.
\end{abstract}

Kata kunci: Alquran; Antisosial; Hadis; Pandangan Islam

Manusia adalah makhluk sosial yang membutuhkan orang lain agar dapat melangsungkan kehidupan. Dalam hubungan antar manusia, atau yang dikenal dengan sebutan hubungan sosial, terdapat pengaruh dan pertalian kebatinan yang terjadi dengan 
sendirinya, yang menjadi unsur sine qua non (yang harus ada) bagi masyarakat (Shadily 1993). Masyarakat bukan hanya terdiri dari beberapa orang atau kelompok saja, di antara mereka juga harus ada rasa kebersamaan, kekeluargaan, atau hubungan timbal balik antara satu dengan yang lainnya. Manusia harus sadar bahwa ada individu lain yang berada di sekitarnya. Menciptakan hubungan yang baik antar individu atau masyarakat tentulah tidak mudah, karena setiap individu memiliki karakter, sifat, dan hal lainnya yang berbeda-beda. Di antara faktor-faktor yang menghambat proses terciptanya hubungan yang baik dalam masyarakat adalah perilaku antisosial.

Antisosial adalah salah satu gangguan kepribadian. Dalam ilmu psikologi disebut dengan antisocial personality disorder (gangguan kepribadian antisosial). Individu-individu dengan gangguan kepribadian antisosial cenderung memiliki riwayat panjang untuk pelanggaran hak-hak orang lain. Mereka sering dideskripsikan sebagai individu yang agresif karena mengambil apa saja yang diinginkan, tanpa peduli perasaan orang lain (Durand dan Barlow 2007).

Dengan kata lain, antisosial adalah suatu penyimpangan tingkah laku yang dilakukan oleh individu, dengan melanggar norma-norma sosial. Biasanya orang-orang ini akan berbuat sesuka hatinya (egois) tanpa memikirkan orang lain. Bahkan, antisosial dapat dicirikan dengan beberapa tanda yaitu memiliki riwayat hidup dalam hal kriminal, waham, pikiran tidak rasional, mudah menjebak orang. Ciri yang lebih parah adalah ketidakadaan rasa penyesalan terhadap perbuatan yang dilakukan karena kurangnya kontrol empati dan perasaan terhadap orang lain (Kusuma dan Sativa 2020).

Setiadi dan Kolip (2011) mengungkapkan bahwa orang dengan perilaku antisosial cenderung hidup dengan selera mereka sendiri, tanpa menyadari apakah selera itu sejalan dengan nilai dan norma sosial yang berlaku. Pendapat orang lain tidak menjadi bahan pertimbangan. Tak jarang jika keinginannya tak terpenuhi, mereka akan berbuat hal yang ekstrem seperti pemerasan, perampokan bahkan pembunuhan. Tak sedikit orang yang mengidap penyakit penyimpangan perilaku ini berasal dari berbagai latar belakang dan usia. Black (2015) menjelaskan bahwa secara epidemiologi, gangguan kepribadian antisosial 
ditemukan sebanyak 2-4\% pada laki-laki dan 0.5-1\% pada wanita. Prevalensi usia puncak ditemukannya kepribadian ini pada usia 24-44 tahun dan menurun pada usia 45-64 tahun.

Dari penjelasan di atas dapat dikatakan bahwa pemicu atau penyebab dari timbulnya penyimpangan tingkah laku antisosial adalah; Pertama, terdapat gangguan mental pada diri seorang individu. Kedua, faktor keturunan atau genetik, yaitu faktor bawaan sejak lahir yang diwarisi dari orang tua. Ketiga, stres. Stres menyebabkan seseorang tidak bisa berpikir secara normal. Orang yang stres akan lebih sensitif dari orang-orang yang biasanya. Keempat, sosiokultural yaitu suatu keadaan sosial dan budaya, tempat orang yang bersangkutan itu hidup dengan daerah-daerah sekelilingnya. Kelima, faktor lingkungan yang tidak baik; serta kurangnya pengawasan, bimbingan, dan arahan dari orang tua akan sangat rentan terjerumus ke dalam hal-hal yang negatif. Keenam, kegagalan belajar mengenai moral dan etika dalam kehidupan awal si penderita, sehingga tanpa di sadari si penderita mengalami stres akibat kesalahpahaman dalam beberapa hal yang belum tuntas ia ketahui, maka akan berujung pada penyimpangan tingkah laku yang tidak baik atau hal negatif lainnya.

Dalam Islam, perilaku sosial merupakan salah satu unsur dalam kehidupan bermasyarakat. Manusia dalam segi bathiniyah diciptakan dari berbagai macam naluri, di antaranya memiliki naluri baik dan jahat. Naluri baik manusia sebagai makhluk sosial itulah yang disebut fitrah, dan naluri jahat apabila tidak dituntun dengan fitrah serta agama akan menjadi naluri yang bersifat negatif (Syaputra 2012). Allah Swt menciptakan manusia secara lengkap yang terdiri dari aspek fisik, psikis, ruh dan juga akal. Kemampuan akal yang dimiliki manusia sesungguhnya sebagai penunjang agar manusia dapat membedakan hal yang baik dan buruk. Melalui akal, manusia dapat melakukan pekerjaan, bersosialisasi dengan lingkungan hingga mengetahui perbuatan yang seharusnya dikerjakan dan yang dihindari. Akal manusia memiliki peranan yang sangat penting. Adanya akal, sehingga manusia dapat dibedakan dengan makhluk lainnya termasuk dengan sesama manusia (Baroroh dan Rosdiyanti 2019).

Dampak signifikan yang ditimbulkan dari perilaku antisosial adalah tidak disenangi oleh orang lain. Sebagian besar pelakunya dinilai tidak baik oleh masyarakat atau mendapatkan perilaku diskriminatif. Setelah menjadi korban, dampak selanjutnya muncul sikap-sikap negatif yang berkontribusi besar bagi perilaku diri sendiri, seperti bunuh diri atau tindakan kekerasan 
yang lainnya. Dampak lain yang ditimbulkan adalah stres, yang disadari atau tidak disebabkan karena tidak adanya komunikasi yang baik atau hubungan timbal balik antara individu yang satu dengan individu yang lainnya. Sikap-sikap negatif yang bersinggungan dengan orang lain atau lingkungan sekitarnya yaitu akan membuat orang lain tidak nyaman, merasa was-was, dan dapat mengganggu kebebasan masyarakat dalam beraktivitas.

Berdasarkan uraian di atas, penelitian ini bertujuan untuk mengurai pengertian antisosial yang bersumber dari berbagai literatur. Selanjutnya, perilaku ini akan diulas dari sudut pandang Islam. Sebagai agama yang memiliki panduan berupa Alquran dan Hadis, setiap pemeluknya harus menjalankan kehidupan sesuai dengan panduan tersebut. Penelitian ini ingin menjelaskan bahwa perilaku antisosial tidak bersesuaian dengan agama Islam, sebab Islam mendorong setiap pemeluknya untuk menciptakan lingkungan masyarakat yang kondusif, harmonis, damai dan menjadi rahmat bagi semesta. Hal ini sejalan dengan prinsip pokok yang terdapat dalam Alquran dan Hadis Rasulullah Saw.

\section{Metode}

Penelitian ini mendeskripsikan perilaku antisosial ditinjau dari sudut pandang ajaran agama Islam. Menggunakan metode kualitatif dalam kajian pustaka (library research). Menghimpun dari berbagai sumber literatur yang relevan untuk menemukan teori, dalil, prinsip, ide, gagasan, pendapat dan sebagainya. Data-data literatur ini dikumpulkan menggunakan metode dokumentasi (Arikunto 1992), sehingga peneliti mendapatkan informasi bukan dari beberapa orang sebagai narasumber, melainkan dari beragam sumber tertulis (Bloor dan Wood 2006).

\section{Hasil dan Pembahasan}

Sosialisasi adalah proses belajar masyarakat tentang nilai-nilai sosial yang berlaku dalam masyarakat tersebut. Melalui proses sosialisasi, kelangsungan hidup suatu kelompok masyarakat budaya dapat terjamin. Dilihat dari wacana psikologi sosial, sosialisasi adalah proses yang memungkinkan individu mengembangkan cara berpikir, berperasaan, dan berperilaku yang berguna bagi penyesuaian sosial efektif dalam hidup bermasyarakat. 
Sosialisasi adalah proses yang berjalan sepanjang hidup manusia, mulai masa anak-anak sampai lanjut usia (Hanurawan 2015). Proses sosialisasi yang baik tentu didukung oleh komunikasi yang baik pula. Ketika melakukan kegiatan sosialisasi, kemampuan berkomunikasi memiliki peran penting dalam berjalannya proses sosialisasi. Adanya komunikasi, akan menghubungkan manusia yang satu dan yang lainnya dalam sebuah interaksi.

Tidak dapat disangkal bahwa komunikasi sangat penting antara sesama manusia yang terlibat dalam suatu hubungan sosial. Komunikasi melibatkan pengiriman dan penerimaan pesan antarindividu. Apabila komunikasi sosial tidak berjalan secara efektif maka pemahaman timbal balik antarindividu menjadi terhambat. Terhambatnya pemahaman timbal balik dapat mengakibatkan terkendalanya hubungan sosial di antara kedua belah pihak yang terlibat dalam proses komunikasi. Komunikasi adalah proses penyampaian informasi, ide, sikap dan emosi dari seseorang kepada orang lain (Hanurawan 2015). Selain komunikasi, sikap juga termasuk hal penting dalam menciptakan hubungan sosial yang baik.

Sama halnya dengan komunikasi, sikap adalah salah satu hal yang tidak bisa di pisahkan dari aktifitas bersosialisasi. Bahkan dalam setiap melakukan interaksi dengan orang lain, sikap bisa menjadi penilaian kedua setelah lisan atau tutur kata yang diucapkan. Strickland (Hanurawan 2015) menjelaskan bahwa sikap adalah predisposisi atau kecenderungan untuk memberikan respon secara kognitif, emosi dan perilaku yang diarahkan kepada suatu objek, pribadi dan situasi khusus dalam cara-cara tertentu. Sikap adalah sebuah pola yang menetap berupa respon evaluatif tentang orang, benda, atau isu. Sikap adalah tendensi (kecenderungan atau kecondongan terhadap sesuatu hal) untuk bereaksi dalam cara suka atau tidak suka terhadap suatu objek. Sikap merupakan emosi atau afek yang diarahkan oleh seseorang kepada orang lain, benda atau peristiwa sebagai objek sasaran sikap.

Sosialisasi, komunikasi, dan sikap adalah suatu komponen penting yang sangat berperan dalam interaksi antar individu. Ketika salah satu dari komponen tersebut tidak berjalan dengan baik maka akan membuat interaksi antar individu menjadi tidak efektif, atau menimbulkan sebuah penyimpangan-penyimpangan. Diantara bentuk penyimpangan yang ditimbulkan adalah perilaku antisosial. Penyimpangan ini muncul disebabkan oleh beberapa faktor, baik faktor internal maupun eksternal. Faktor internal misalnya pengaruh genetik. Akan 
tetapi faktor genetik muncul bila ada pengaruh-pengaruh lingkungan tertentu bila ada predisposisi genetik tertentu. Faktor genetik mungkin menunjukkan adanya kerentanan tertentu, tetapi perkembangan kriminalitas secara aktual didorong oleh faktor-faktor eksternal atau lingkungan, seperti kurangnya kontak berkualitas tinggi dengan orang tua pada masa kanak-kanak. Hal ini dibuktikan dari penelitian yang dilakukan oleh Damayanti dan Lestari (2018) yang meneliti tentang perilaku antisosial pada remaja yang orangtuanya bercerai.

Dalam deskripsi klinis menurut sudut pandang psikologi, antisosial adalah orang yang mementingkan dirinya sendiri dan tidak peduli kepada orang lain, berulah sesuka hati dan semena-mena terhadap orang lain, melakukan penipuan atau pemalsuan identitas. Penderita sering tidak melihat perbedaan antara kebenaran dan kebohongan ucapannya demi tercapai tujuannya. Dalam menjalankan perilaku buruknya tersebut penderita antisosial ini sama sekali tidak merasakan nervous (gugup), bahkan tidak merasa bersalah atau ada penyesalan dalam dirinya. Lebih mengkhawatirkan lagi sebab tanda-tanda tersebut bisa menjadi pola seumur hidup bagi sebagian penderita gangguan antisosial (Hanurawan 2015).

Gangguan kepribadian antisosial pernah memiliki sejumlah nama yang berbeda selama bertahun-tahun. Philippe Pinel mengidentifikasikannya sebagai manie sans delire (mania tanpa delirium) untuk mendeskripsikan penderita respon-respon emosional yang tidak lazim dan ledakan-ledakan kemarahan impulsif tetapi tidak menunjukkan defisit dalam kemampuan penalarannya. Label-label lain yang pernah digunakan termasuk "moral insanity" (kegilaan moral), "egopathy", "sociopathy", dan "psychopathy" (Durand dan Barlow 2007).

Seorang anak yang mendapatkan pendidikan yang baik dari orang tuanya akan tumbuh dan berkembang secara baik dengan didukung oleh lingkungan sosial yang baik pula. Sikap seorang anak atau individu yang baik adalah berkelakuan sopan santun, tidak melanggar norma-norma yang berlaku baik norma agama, sosial, adat dan sebagainya. Mampu berkomunikasi baik dengan orang sekitarnya dan bersikap ramah. Hal tersebut akan menciptakan hubungan sosial yang harmonis. Jika seorang individu telah mampu tumbuh dan berkembang seperti itu, maka tidak akan muncul perilaku yang menyimpang. 


\section{Antisosial Dalam Pandangan Islam}

Islam adalah agama yang rahmatan lil 'alamin, yang mengatur segala bentuk kehidupan manusia dari hal yang kecil sampai hal yang besar. Baik berupa cara hidup, berinteraksi dengan sesama makhluk Allah Swt, maupun hal yang lainnya. Dari berbagai hal yang diatur dalam Islam, tingkah laku atau akhlak adalah poin penting yang harus dimiliki oleh setiap Muslim.

Akhlak berasal dari bahasa Arab (Munawwir 1997), yaitu isim mashdar (bentuk infinitif) dari kata akhlaqa, yukhliqu, ikhlaqan, sesuai dengan pertimbangan (wazan) tsulasi mazid af'ala, yuf'ilu, if'alan yang berarti al-sajiyah (perangai), ath-thabi'ah (kelakuan, tabi'at, watak dasar), al'adat (kebiasaan, kelaziman), dan al-maruah (kesopanan). Akar kata akhlak dari akhlaqa sebagaimana tersebut di atas tampaknya kurang pas, sebab isim mashdar dari kata akhlaqa bukan akhlaq tetapi ikhlaq. Berkenaan dengan ini maka timbul pendapat yang mengatakan bahwa secara linguistik kata akhlaq merupakan isim jamid atau isim ghairu musytaq, yaitu isim yang tidak memiliki akar kata, melainkan kata tersebut memang sudah demikian adanya. Kata akhlaq adalah jamak dari kata khilqun atau khuluqun yang artinya telah diurai di atas. Baik kata akhlaq atau khuluq keduanya dijumpai pemakaiaannya dalam Alquran dan Hadis, sebagai berikut:

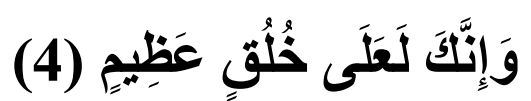
Terjemahnya: "Dan Sesungguhnya kamu benar-benar berbudi pekerti yang agung." (QS. Al-Qalam/68: $4)$.

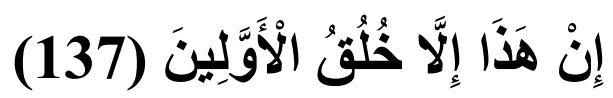
Terjemahnya: "(agama Kami) ini tidak lain hanyalah adat kebiasaan orang dahulu." (QS. Al-Syu'ara/26: 137).

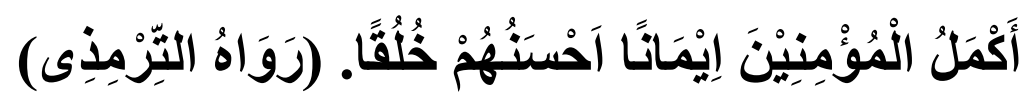

Artinya: "Orang mukmin yang paling sempurna keimanannya adalah orang sempurna budi pekertinya." (HR. Tirmidzi).

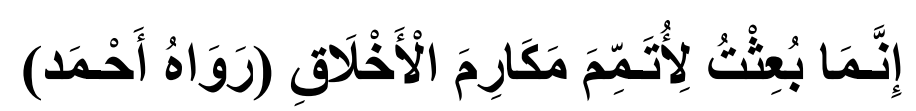

Artinya: "Bahwasanya aku diutus (Allah) untuk menyempurnakan keluhuran budi pekerti." (HR. Ahmad).

Ayat yang terdapat pada Surah Al-Qalam: 4 di atas menggunakan kata khuluq untuk arti budi pekerti, sedangkan pada Surah Al-Syu'ara: 137 untuk arti adat kebiasaan. Selanjutnya 
Hadis yang diriwayatkan oleh Imam Tirmidzi menggunakan kata khuluq untuk arti budi pekerti, dan hadis kedua menggunakan kata akhlaq yang juga berarti budi pekerti. Dengan demikian kata ahklaq atau khuluq secara kebahasaan berarti budi pekerti, adat kebiasaan, perangai, atau segala sesuatu yang sudah menjadi tabi' at.

Untuk menjelaskan pengertian akhlak dari segi istilah ini dapat merujuk pada berbagai pendapat pakar di bidang ini. Salah satunya Ibnu Miskawaih yang selanjutnya dikenal sebagai pakar bidang akhlak terkemuka dan terdahulu. Secara singkat Ibnu Miskawaih (Al-Ghazali t.t.) mengatakan bahwa akhlak adalah;

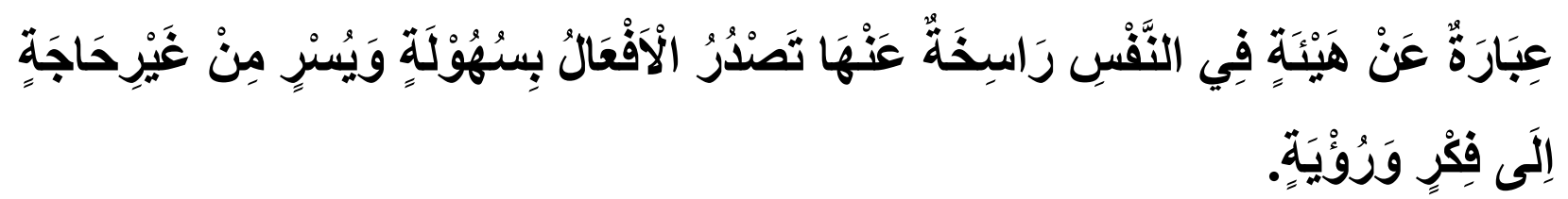

Artinya: "Sifat yang tertanam dalam jiwa manusia yang menimbulkan macam-macam perbuatan dengan gampang dan mudah, tanpa memerlukan pemikiran dan pertimbangan.

Keseluruhan definisi akhlak tersebut di atas tampak tidak ada yang bertentangan, melainkan memiliki kemiripan antara satu dan lainnya, yang seluruhnya membahas tentang tingkah laku. Ajaran Islam adalah ajaran yang bersumberkan wahyu Allah Swt. Bahasan mengenai akhlak atau tingkah laku dalam ajaran Islam mendapatkan perhatian yang sangat besar sebagaimana yang telah dijelaskan pada Ayat Alquran dan Hadis yang telah disebutkan di atas.

Menurut ajaran Islam, penentuan baik dan buruknya suatu tingkah laku harus didasarkan pada petunjuk Alquran dan Hadis. Rasulullah Saw. adalah teladan bagi umat Muslim dalam seluruh aspek kehidupan termasuk tingkah laku beliau. Imam Abu Daud dan Imam Nasai telah meriwayatkan akhlak Rasulullah melalui hadis Al-Hasan: "Ibnu Jarir mengatakan, telah menceritakan kepadaku Yunus, telah menceritakan kepada kami Ibnu Wahb, dari Abuz Zahiriyah, dari Jubair ibnu Nafir yang mengatakan bahwa ia melakukan ibadah haji, lalu mengunjungi Aisyah r.a. dan menanyakan kepadanya tentang akhlak Rasulullah Saw. Maka ia menjawab: Akhlak Rasulullah Saw adalah Alquran".

Makna yang dimaksud pada Hadis tersebut menunjukkan bahwa Rasulullah Saw, adalah seorang yang mengamalkan Alquran; mengamalkan perintah Allah Swt. dan menjauhi 
larangannya, yang hal ini telah tertanam dalam diri beliau sebagai watak dan pembawaannya serta sebagai akhlak yang telah terpatri dalam sepak terjang beliau. Maka apa pun yang diperintahkan oleh Alquran, beliau pasti mengerjakannya; dan apapun yang dilarang oleh Alquran, beliau pasti meninggalkannya. Selain watak yang dibekalkan oleh Allah dalam diri beliau tersebut, Rasulullah Saw. juga dikenal memiliki sifat pemalu, dermawan, berani, pemaaf, penyantun, dan semua akhlak yang terpuji lainnya. Rasulullah Saw. adalah panutan setiap Muslim dalam bersikap dan bertingkah laku, sehingga seorang Muslim harus taat kepada Allah dan Rasul-Nya. Sebaliknya, bersikap membangkang terhadap perintah Allah dan Rasul-Nya adalah perbuatan yang buruk, karena bertentangan dengan Alquran dan Al-Sunnah.

Antisosial menjadi salah satu tingkah laku yang buruk karena bertentangan dengan Alquran dan Hadis, seperti dalam Surah Al-Hujurat/49: 13,

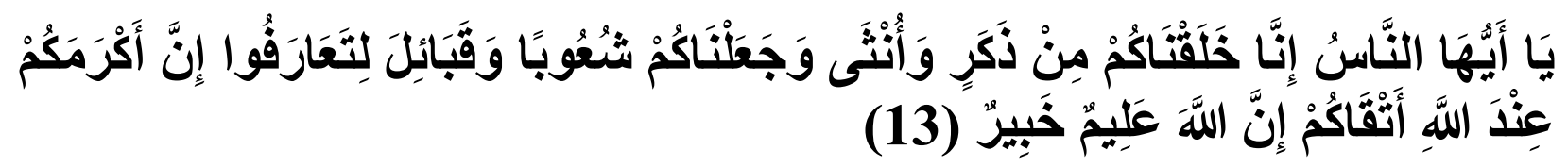

Terjemahnya: “Hai manusia, Sesungguhnya Kami menciptakan kamu dari seorang laki-laki dan seorang perempuan dan menjadikan kamu berbangsa-bangsa dan bersuku-suku supaya kamu saling kenal-mengenal. Sesungguhnya orang yang paling mulia diantara kamu disisi Allah ialah orang yang paling taqwa diantara kamu. Sesungguhnya Allah Maha mengetahui lagi Maha Mengenal".

Ayat di atas menyebutkan bahwa Allah Swt. menciptakan manusia dari lelaki dan perempuan dan menjadikannya berbangsa-bangsa dan bersuku-suku supaya saling kenal mengenal. Artinya Alquran menyampaikan agar manusia harus saling berinteraksi secara baik dengan sesama. Perilaku antisosial bertolak belakang dengan hal ini. Dalam sebuah Hadis disebutkan bahwasanya Rasulullah Saw. bersabda:

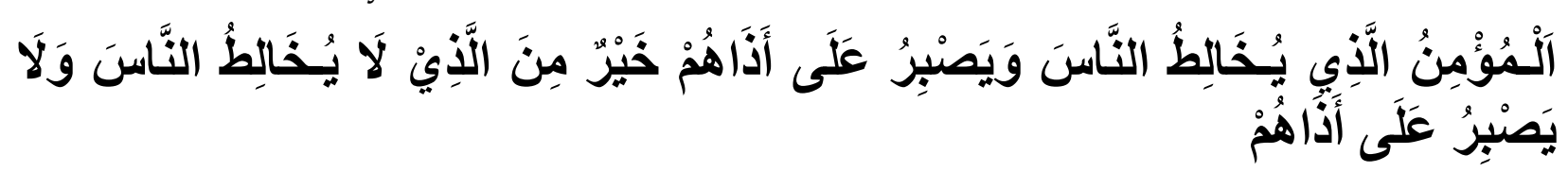

Artinya: "Seorang mukmin yang bergaul di tengah masyarakat dan bersabar terhadap gangguan mereka, itu lebih baik dari pada seorang mukmin yang tidak bergaul di tengah masyarakat dan tidak bersabar terhadap gangguan mereka" (HR. At-Tirmidzi 2507, Al-Bukhari dalam Adabul Mufrad 388, Ahmad 5/365, syaikh Musthafa Al 'Adawi mengatakan hadis ini shahih dalam Mafatihul Figh 44). 


\section{Kesimpulan}

Berdasarkan ulasan yang telah diuraikan dapat disimpulkan bahwa perilaku antisosial berseberangan dengan prinsip ajaran Agama Islam. Dalam Alquran maupun Hadis, setiap Muslim diperintahkan untuk menjalin interaksi yang baik dengan sesama melalui kemampuan komunikasi dan sikap yang santun. Hal ini juga dimaksudkan agar dapat mewujudkan potret masyarakat yang damai, harmonis dan kondusif.

Saran

Perilaku antisosial yang dicirikan dengan waham, pikiran tidak rasional, mudah menjebak orang, tidak peduli dengan kondisi sekitar, bahkan tidak punya rasa penyesalan karena melakukan perbuatan tersebut dapat menciderai prinsip ajaran Islam yang dibawa oleh Nabi Saw. Sehingga menjadi penting untuk mengenali ciri-ciri antisosial kemudian menghindarkan diri dari perilaku tersebut dan juga mencegah orang lain berbuat demikian.

\section{Referensi}

Al-Ghazali, Imam. t.t. 3 - إحباء علوم الدين - مكتبه كرياطه فوترا - سعاراغ - اندونبيسيا. Semarang: Toha Putra. Arikunto, Suharsimi. 1992. Prosedur Penelitian: Suatu Pendekatan Praktik. Jakarta: Rineka Cipta.

Baroroh, Nurdhin, dan Nike Rosdiyanti. 2019. “Status Pertanggungjawaban Pelaku Tindak Pidana Bagi Penderita Gangguan Mental Kategori Kepribadian Antisosial Perspektif Hukum Positif dan Hukum Islam." 7:15.

Black, Donald W. 2015. "The Natural History of Antisocial Personality Disorder." The Canadian Journal of Psychiatry 60(7):309-14.

Bloor, Michael, dan Fiona Wood. 2006. Keywords in Qualitative Methods a Vocabulary of Research Concepts. London: SAGE.

Damayanti, Febriana Krisma, dan Sri Budi Lestari. 2018. "Memahami Komunikasi Keluarga Dalam Mengelola Perilaku Antisosial Pada Remaja yang Orangtuanya Bercerai." Interaksi Online 6(2):193-203.

Durand, V. Mark, dan David H. Barlow. 2007. Intisari Psikologi Abnormal. 4 ed. Yogyakarta: Pustaka Pelajar.

Hanurawan, Fattah. 2015. Psikologi Sosial: Suatu Pengantar. Bandung: PT Remaja Rosdakarya.

Kusuma, Annisa Dwianggreni, dan Shania Ocha Sativa. 2020. "Karakteristik Kepribadian Antisosial." Jurnal Keperawatan Jiwa 8(1):33-36.

Munawwir, Ahmad Warson. 1997. Al-Munawwir: Kamus Arab-Indonesia.

Setiadi, Elly M., dan Usman Kolip. 2011. Pengantar Sosiologi: Pemahaman Fakta dan Gejala Permasalahan Sosial. Jakarta: Kencana.

Shadily, Hassan. 1993. Sosiologi Untuk Masyarakat Indonesia. 12 ed. Jakarta: Rineka Cipta. 
Syaputra, Elvan. 2012. "Islam dan Perilaku Sosial." Republika Online. Diambil 2 Juni 2020 (https://republika.co.id/berita/jurnalisme-warga/wacana/12/11/21/mdtwqu-islam-danperilaku-sosial).

\begin{tabular}{|l|l|l|l|l|}
\hline Submit & Review & Revisi & Diterima & Publis \\
\hline 02-06-2020 & 05-10-2020 sd 23-11-2020 & $23-11-2020$ & $23-11-2020$ & $27-1-2021$ \\
\hline
\end{tabular}

Haryani Putriani dan Ihsan Mz

Institut Agama islam negeri Palangkaraya

Email : haryaniputriana99@gmail.com, ihsan.mz@iain-palangkaraya.ac.id 